To be cited as: Sušnik, J., Vamvakeridou-Lyroudia, L.S., Gebert, N., Kloos, J., Renaud, F. La Jeunesse, I., Mabrouk, B., D.A. Savić, Kapelan, Z. Ludwig, R., Fischer, G., Roson, R., and Zografos, C., (2014), Interdisciplinary assessment of sealevel rise and climate change impacts on the lower Nile delta, Egypt, Science of the Total Environment, Vo. 503, pp.

279-288, doi: 10.1016/j.scitotenv.2014.06.111.

\title{
INTERDISCIPLINARY ASSESSMENT OF SEA-LEVEL RISE AND CLIMATE CHANGE IMPACTS ON THE LOWER NILE DELTA, EGYPT
}

\author{
Janez Sušnik ${ }^{12^{\star}}$, Lydia S. Vamvakeridou-Lyroudia ${ }^{1}$, Niklas Baumert ${ }^{3}$, Julia Kloos ${ }^{3}$, \\ Fabrice G. Renaud ${ }^{3}$, Isabelle La Jeunesse ${ }^{4}$, Badr Mabrouk ${ }^{5}$, Dragan A. Savić ${ }^{1}$, Zoran \\ Kapelan', Ralf Ludwig ${ }^{6}$, Georg Fischer ${ }^{6}$, Roberto Roson ${ }^{7,8}$, Christos Zografos ${ }^{9}$ \\ ${ }^{1}$ Centre for Water Systems, College of Engineering, Mathematics and Physical Sciences, \\ University of Exeter, Exeter, UK
}

${ }^{2}$ Now at: UNESCO-IHE Institute for Water Education, Integrated Water Systems and Governance Department, Westvest 7, PO Box 3015, 2601, Delft, The Netherlands

${ }^{3}$ United Nations University, Institute for Environment and Human Security, Bonn,

Germany

${ }^{4}$ Université François Rabelais de Tours, Tours, France

${ }^{5}$ University of Zagazig, Zagazig, Egypt

${ }^{6}$ Ludwig-Maximilians-Universität München (LMU), Department of Geography, Munich,

Germany

${ }^{7}$ Ca'Foscari University, Venice, Italy

${ }^{8}$ IEFE, Bocconi University, Milan, Italy

${ }^{9}$ Institute of Environmental Science and Technology (ICTA), Universitat Autònoma de Barcelona, Barcelona, Spain

*Corresponding author. Email: j.susnik@unesco-ihe.org

Keywords: climate change impacts; interdisciplinary research; Nile delta; water resources. 
To be cited as: Sušnik, J., Vamvakeridou-Lyroudia, L.S., Gebert, N., Kloos, J., Renaud, F. La Jeunesse, I., Mabrouk, B., D.A. Savić, Kapelan, Z. Ludwig, R., Fischer, G., Roson, R., and Zografos, C., (2014), Interdisciplinary assessment of sealevel rise and climate change impacts on the lower Nile delta, Egypt, Science of the Total Environment, Vo. 503, pp. 279-288, doi: 10.1016/j.scitotenv.2014.06.111.

\section{Abstract}

CLImate-induced changes on WAter and SECurity (CLIWASEC) was a cluster of three complementary EC-FP7 projects assessing climate change impacts throughout the Mediterranean on: hydrological cycles (CLIMB - CLimate-induced changes on the hydrology of Mediterranean Basins); water availability and security (WASSERMed Water Availability and Security in Southern EuRope and the Mediterranean) and human security connected with possible hydro-climatic conflicts (CLICO - CLImate change hydro-COnflicts and human security). One case study area - the Nile delta, Egypt - was common between the projects. CLIWASEC created a common scientific forum for modelling and monitoring to understand potential impacts across sectors in an integrated way. This paper summarises key project results from an integrated assessment of potential challenges to water-related security issues in the Mediterranean, focussing on potential sea-level rise impacts by the middle of the century. We use the common focus between the projects to illustrate the added value of project clustering.

The CLIWASEC approach pursues multidisciplinary research by adopting a single research objective: sea-level rise related water security threats. This results in deeper understanding and a more holistic view of problems and potential solutions in the lower Nile. Through fragmented research results, policy-makers do not get the 'bigger picture', and fail to understand how multiple issues can materialize from one driver. By combining efforts in one case study area, and addressing one driver, an integrated assessment of climate-related water security threats in the lower Nile region may be formulated, offering policy and decision makers a clearer picture of how inter-related issues to society and the environment can arise. For example, we show that the main issues identified by each project individually (land subsidence and salt-water intrusion - CLIMB; water supply overexploitation, land loss due to SLR and inefficient cropping - WASSERMed; lack of employment options and housing security - CLICO), while important in their own right are 
To be cited as: Sušnik, J., Vamvakeridou-Lyroudia, L.S., Gebert, N., Kloos, J., Renaud, F. La Jeunesse, I., Mabrouk, B., D.A. Savić, Kapelan, Z. Ludwig, R., Fischer, G., Roson, R., and Zografos, C., (2014), Interdisciplinary assessment of sealevel rise and climate change impacts on the lower Nile delta, Egypt, Science of the Total Environment, Vo. 503, pp. 279-288, doi: 10.1016/j.scitotenv.2014.06.111.

in fact related. (Ground-) water overexploitation by agriculture is exacerbating the land subsidence and salt-water intrusion issues. This is turn could impact on employment opportunities and may lead to the loss of housing stock as a result of building collapse. All this has wider implications for development in the region. This richer understanding could be critical in making better policy decisions when attempting to mitigate climate and social change impacts. We show that the CLIWASEC clustering offers an encouraging path for other efforts in the new European Commission Horizon 2020 programme to follow.

\section{The CLIWASEC cluster: scope and background}

Climate change has been one of the main topics in the European Union's environmental policy since 1988. The EU took leadership in developing multilateral climate protection policies in highlighting climate change as a major security issue. In this context, collaborative research projects related to climate change impacts are supported by the European Commission. Climate change is impacting the Mediterranean region in myriad and distinct ways including increased frequency of flash flood events, droughts or periods of water shortages and rising temperatures (e.g. Christensen and Christensen, 2007; Giannakopoulos et al. 2009). Sea level rise is also an important issue (IPCC, 2013). Observed trends and projections for the future indicate a strong susceptibility to changes in hydrological regimes, an increasing general shortage of water resources and consequent threats to water availability and management. However, it must be clearly stated that as a result of current uncertainties in climate projections and subsequent impact models, an incomplete understanding of the impact of a climate change signal on economic mechanisms or the lack of an elaborate and integrated human security conceptual framework limitations are being imposed on water-related decision-making under conditions of climate change (IPCC, 2013). 
To be cited as: Sušnik, J., Vamvakeridou-Lyroudia, L.S., Gebert, N., Kloos, J., Renaud, F. La Jeunesse, I., Mabrouk, B., D.A. Savić, Kapelan, Z. Ludwig, R., Fischer, G., Roson, R., and Zografos, C., (2014), Interdisciplinary assessment of sealevel rise and climate change impacts on the lower Nile delta, Egypt, Science of the Total Environment, Vo. 503, pp. 279-288, doi: 10.1016/j.scitotenv.2014.06.111.

CLImate-induced changes on WAter and SECurity (CLIWASEC; http://www.cliwasec.eu) was a cluster of three complementary, interdisciplinary European Commission Seventh Framework (EC-FP7) funded projects focussing on various socio-physical water-related issues throughout the Mediterranean (Ludwig et al., 2011). The clustering brought together 44 partner institutions from across Europe and the Mediterranean, representing a critical mass of scientific knowledge, capability and collaboration with local stakeholders. In the CLIWASEC cluster, there were 23 study sites throughout southern Europe, the Mediterranean, the Middle East and north Africa (Figure 1), representing regions with diverse climate, societal and water-related threats being posed to equally diverse populations, levels of development and governmental systems. Of these study sites, the Nile delta region, Egypt (Figure 1), was common between the projects, and is the focus of this paper.

The three projects comprising the CLIWASEC cluster were: CLIMB (CLimate-Induced changes on the hydrology of Mediterranean Basins); WASSERMed (Water Availability and Security in Southern EuRope and the Mediterranean) and; CLICO (CLImate change hydro-COnflicts and human security). These projects had wide and differing remits, but all focussed on a range of water-related security issues throughout the Mediterranean. With respect to this paper, CLIMB (www.climb-fp7.eu), focuses on climate change impacts to hydrological cycles, using extensive field measurements and multi-parametric remote sensing to monitor environmental change and to parameterise and interface land surface models with hydrogeological models in the western Nile Delta. WASSERMed (www.wassermed.eu) was focused on assessing water-related security threats, including those to agriculture, tourism and economies. System Dynamics (Ford, 1999) is used to assess water-related security concerns in Rosetta (Nile Delta), incorporating agricultural and trade issues. Focusing on the Mediterranean, the Middle East and the Sahel, some of the global regions most exposed and vulnerable to hydro-climatic changes, CLICO's 
To be cited as: Sušnik, J., Vamvakeridou-Lyroudia, L.S., Gebert, N., Kloos, J., Renaud, F. La Jeunesse, I., Mabrouk, B., D.A. Savić, Kapelan, Z. Ludwig, R., Fischer, G., Roson, R., and Zografos, C., (2014), Interdisciplinary assessment of sealevel rise and climate change impacts on the lower Nile delta, Egypt, Science of the Total Environment, Vo. 503, pp. 279-288, doi: 10.1016/j.scitotenv.2014.06.111.

(www.clico.org) aim was to understand under what conditions hydro-climatic hazards intensify social tensions or provide a catalyst for cooperation. In the Greater Alexandria case study, the focus for this paper was on the anticipation of potential human security risks arising from a hypothetical scenario of large scale preventative resettlement in response to sea-level rise (SLR). For the purposes of this paper, we use the common Nile delta study area and a common driver (SLR) to highlight the added value of project clustering as opposed to analysing the results from the three projects individually. Figure 2 illustrates conceptually how the projects interacted, and the aspects that each project focussed on to contribute to the integrated assessment presented in this paper.

Egypt has a population of 75 million, $51 \%$ of whom live in rural areas and $49 \%$ in cities. Its annual average rainfall is characteristic of arid regions and ranges, from south to north, from 51 to $200 \mathrm{~mm}$ (OIE). The volume of water consumed in Egypt is $68 \mathrm{~km}^{3}$ of which $86 \%$ is dedicated to agriculture. Ninety-five percent of the water derives from the river Nile which crosses in total 10 countries on its $6500 \mathrm{~km}$ course. In the context of the construction of the Grand Ethiopian Renaissance Dam under construction on the upper Nile, geopolitical stability requires a better knowledge on water threats over the region.

While the CLIWASEC projects had wide research remits, for the purposes of the interdisciplinary research presented in this paper, we focus solely on those impacts to the Nile delta that are related to local sea-level rise. Regarding the general CLIWASEC thematic setting, a majority of plausible hydro-climatic projections suggest lower Nile flow availability for Egypt in the future mainly resulting from regional climate change and social changes such as population growth and development, and increases in SLR. These changes will have considerable impacts on society and regional economic activity. However there is considerable uncertainty in these predictions. For example, estimates of changes to Nile flow volumes relative to today range from $+60 \%$ to $-50 \%$ (Conway, 2005 ; Kingston and Taylor, 2010; Beyene et al., 2011). Dasgupta et al. (2007) and El-Raey 
To be cited as: Sušnik, J., Vamvakeridou-Lyroudia, L.S., Gebert, N., Kloos, J., Renaud, F. La Jeunesse, I., Mabrouk, B., D.A. Savić, Kapelan, Z. Ludwig, R., Fischer, G., Roson, R., and Zografos, C., (2014), Interdisciplinary assessment of sealevel rise and climate change impacts on the lower Nile delta, Egypt, Science of the Total Environment, Vo. 503, pp. 279-288, doi: 10.1016/j.scitotenv.2014.06.111.

(2010) provide estimates on the decline of national income and other physical and socioeconomic impacts for a range SLR scenarios. Based on these studies, there are existing social, economic, and political problems that will be exacerbated by SLR. In addition, the 'Arab Spring' of 2011 highlighted the potential for dramatic, sudden social and governmental change to introduce considerable uncertainty into estimates for the future development of populations and/or governance structures. Furthermore, taking into account projected SLR over and above expected local land subsidence (for the Alexandria region of the Nile delta, land subsidence alone is currently estimated at 0.4 $2.0 \mathrm{~mm} \mathrm{yr}^{-1}$, El-Raey et al., 1999) this is likely to cause increasing loss of low-lying coastal areas which are particularly important for agriculture and local economies, and will lead to sea water intrusion into near-coastal aquifers, impacting on coastal freshwater sources. It is predicted that agricultural activity on the Nile delta could be considerably affected by SLR. This will also be the case for coastal populations and the predicted yetto-be urbanised Alexandria hinterland as a large portion of land is lost to SLR, subsidence, and environmental degradation. For example, a SLR of $0.5 \mathrm{~m}$ above land subsidence in the Nile Delta would affect c. 3.8 million people and $1800 \mathrm{~km}^{2}$ of cropland, while SLR of $1 \mathrm{~m}$ by 2100 would directly impact 6.1 million people and $4500 \mathrm{~km}^{2}$ of cropland (Fitzgerald et al., 2010). The strongly growing population will be exposed to an increasing risk of extreme events, such as flooding following storm surges (Dasgupta et al., 2009), and will put increasing pressure on available water resources and financial resources for protecting vulnerable coastal areas.

It is clear that a range of climate and social changes could converge to impact the Nile delta area in a range of natural-societal ways. In order to properly assess how any impact may affect the Nile delta area as a whole, integrated, interdisciplinary assessment of the problems and of the impacts is required. This is what the CLIWASEC cluster of projects aimed to achieve by combining work from a water-resources, a hydrological and a social- 
To be cited as: Sušnik, J., Vamvakeridou-Lyroudia, L.S., Gebert, N., Kloos, J., Renaud, F. La Jeunesse, I., Mabrouk, B., D.A. Savić, Kapelan, Z. Ludwig, R., Fischer, G., Roson, R., and Zografos, C., (2014), Interdisciplinary assessment of sealevel rise and climate change impacts on the lower Nile delta, Egypt, Science of the Total Environment, Vo. 503, pp.

279-288, doi: 10.1016/j.scitotenv.2014.06.111.

science point of view at one common case study area focusing on one driver. The complementarity between the three CLIWASEC projects allows for integration of the different results for the region. The results, due to their breadth, could be used to derive policy recommendations for decision makers, the Water Framework Directive, EU policy in general and how future projects could be better clustered. This work highlights lessons learnt as a result of such a multi-project, multi-disciplinary undertaking (Quevauvillier et al., 2012). This paper summarises pertinent results for the Nile delta region from each project individually and provides a synthesis of the complexity apparent resulting potential consequences, with commentary regarding the added value due to the clustering of these three research projects, and for future research projects.

\section{Hydrological change and SLR impacts on infrastructure in the Greater}

\section{Alexandria area}

The CLIMB research framework was based on the implementation of multi-model hydrometeorological ensembles and the comparison of changing hydrological quantities from a reference (1971-2000) to a projection period (2041-2070). The analyses revealed a general reduction in annual precipitation sum of varying magnitude, moderate shifts in the seasonal rainfall patterns, and an overall increase in drought risk. In conjunction with higher temperatures in all seasons and the consequent increase in potential evapotranspiration (ETpot), the actual evapotranspiration (ETact) diminishes as a result of drier soils. Overall in the Nile delta, including the coastal regions, changes in in-situ hydrological quantities remain relatively small and, due to the little amounts of change, below the level of model uncertainty. Only temperatures increase considerably, the projected reduction of precipitation is very low $(-2 \%)$ and results in a slightly decreased soil water content. Existing pressures on water resources, partly related to climate change, are however diverse; the region is highly vulnerable due to urbanization, soil and groundwater salinisation, pollution, land degradation and poor management practices 
To be cited as: Sušnik, J., Vamvakeridou-Lyroudia, L.S., Gebert, N., Kloos, J., Renaud, F. La Jeunesse, I., Mabrouk, B., D.A. Savić, Kapelan, Z. Ludwig, R., Fischer, G., Roson, R., and Zografos, C., (2014), Interdisciplinary assessment of sealevel rise and climate change impacts on the lower Nile delta, Egypt, Science of the Total Environment, Vo. 503, pp. 279-288, doi: 10.1016/j.scitotenv.2014.06.111.

(e.g. El-Sadek, 2010; Gohar and Ward, 2010; Shaban et al., 2010). Notably, stakeholder interviews revealed that population growth and urbanization are considered the main pressures on water resources for the next 20 years, dominant even over agricultural irrigation. For the Nile delta, the situation is expected to become more complex due to the superposition of geopolitical issues around transboundary river systems.

In addition, CLIMB utilised field measurements and multi-parametric remote sensing to monitor environmental change to parameterise and interface land surface models and hydrogeological models in the western Nile delta around Alexandria. The toolset developed and the corresponding results reveal local land subsidence to be in-part related to overexploitation of groundwater and consequent seawater intrusion. Climate projections for the region indicate an increase in annual surface freshwater volume deficit, a result mirrored in WASSERMed (Sušnik et al., 2013, Section 3). This deficit will impose additional demands on irrigation and domestic water supply, potentially leading to even greater levels of groundwater exploitation, exacerbating the problem. This in turn has implications for the general state of water security in the region, which is also threatened by landward propagation of saline groundwater due to over-pumping and land loss due to SLR.

The majority of salt-affected soils in Egypt are located in the northern-central part of the Nile Delta on its eastern and western sides (Gehad, 2003). With approximately 900000 ha of cultivated irrigated areas suffering from salinisation problems, c. $60 \%$ of the cultivated lands of the northern Delta region are salt-affected. This has important implications for crop production in the region, which is a key part of the local economy. In some coastal areas, especially in the Greater Alexandria Area, the extraction of groundwater for irrigation and domestic supply has proceeded to the point where intrusion of saline seawater has seriously degraded the quality of these resources (Kotb et al., 2000). 
To be cited as: Sušnik, J., Vamvakeridou-Lyroudia, L.S., Gebert, N., Kloos, J., Renaud, F. La Jeunesse, I., Mabrouk, B., D.A. Savić, Kapelan, Z. Ludwig, R., Fischer, G., Roson, R., and Zografos, C., (2014), Interdisciplinary assessment of sealevel rise and climate change impacts on the lower Nile delta, Egypt, Science of the Total Environment, Vo. 503, pp. 279-288, doi: 10.1016/j.scitotenv.2014.06.111.

In addition to the impact on soil degradation, pronounced sea-water intrusion into nearcoastal aquifers due to groundwater overexploitation, coupled with SLR, has destabilised the clayey alluvial soils. This effect exacerbates the tendency for land subsidence, with small scale local topographic deformation, including the formation of major cavities and the spontaneous formation of sinkholes (Mohamed et al. 2008), causing severe damage to buildings and critical infrastructure. In recent years, this effect has been responsible for several building collapses and casualties in the Alexandria region. Many buildings are abandoned or at serious risk of becoming uninhabitable, increasing the probability for further resettlement of the local population (see the related impact of this in Section 4).

CLIMB has employed a rigorous image analysis procedure, conventional Differential Synthetic Aperture Radar (DiffSAR; Berardino et al., 2003) and Interferometric Point Target Analysis using multitemporal Advanced SAR (ASAR) imagery (Werner, 2003; Zhang et al., 2011), to identify land subsidence in the Greater Alexandria area. The overall concept is based on the assumption that when lowering the hydraulic head in a hydrogeological system by pumping groundwater, effective stresses increase. This increase is responsible for the compaction of compressible layers within the coupled ground-water system and eventually for land surface subsidence. After precise coregistration of imagery and the generation of interferograms, the topographic phase contribution was removed by using shuttle radar topography mission (SRTM) data to estimate the displacement contribution. The Persistent Scatterer Interferometry technique (PSI, Ferretti et al., 1999; Laukens et al., 2010) was developed and applied to eliminate the topographic contribution and allow for measurements of displacement (land subsidence) in the sub-centimeter range.

Figure 3 shows the average annual displacement velocity, as determined by means of PSI applied to imagery from 2006-2010 for the Alexandria Governorate (map on left of Fig. 3). While being in good accordance with average annual subsidence rates given in 
To be cited as: Sušnik, J., Vamvakeridou-Lyroudia, L.S., Gebert, N., Kloos, J., Renaud, F. La Jeunesse, I., Mabrouk, B., D.A. Savić, Kapelan, Z. Ludwig, R., Fischer, G., Roson, R., and Zografos, C., (2014), Interdisciplinary assessment of sealevel rise and climate change impacts on the lower Nile delta, Egypt, Science of the Total Environment, Vo. 503, pp. 279-288, doi: 10.1016/j.scitotenv.2014.06.111.

the literature (El-Raey, 2010), the range of values $(-7$ to $+7 \mathrm{~mm})$ reveal the small scale spatial variability of topographic deformation and explains the stress and consequences of displacement upon the built infrastructure in the urban centre of the region (images on right of Fig. 3). The techniques developed and applied as part of the CLIMB project show how different data sources can be successfully integrated to assess the damage potential to urban areas as a result of overexploitation of groundwater resources, highlighting a different aspect to the water resources work of WASSERMed (Section 3). These results could have important implications for relocation of local citizens, a process which was studied in detail in CLICO (Section 4), for future urban development in the region, and may inform future groundwater pumping rules and regulations such that further detrimental impacts to infrastructure and soil and water quality can be minimised.

\section{Examining SLR impacts on water and food security in Rosetta}

WASSERMed, with a focus on the water-agricultural system, used System Dynamics Modelling (Ford, 1999; Sušnik et al. 2012) to assess water security concerns in the water, food and economic sectors in the Rosetta region of the Nile delta (Figure 4; Sušnik et al., 2013). The systems model was developed specifically for this project, allowing it to be targeted to the requirements of the project and of the local partner/stakeholder. The integrated systems model was developed in cooperation with local WASSERMed partner ECRI (Environmental and Climate Change Research Institute). This ensured that the model structure was suitable to the problem being studied, that necessary data were available, that the model objectives and expectations were realistic and that results were reasonable, representative and ultimately useful. While water-balance assessment was the main objective of the model and the project, modelling efforts were extended to include analysis of crop yield and revenue for the Rosetta study area, assessing the impact of a) altering cropping patterns on the local irrigation water demand, water balance, crop yield and revenue, and; b) exploiting international markets and developing 
To be cited as: Sušnik, J., Vamvakeridou-Lyroudia, L.S., Gebert, N., Kloos, J., Renaud, F. La Jeunesse, I., Mabrouk, B., D.A. Savić, Kapelan, Z. Ludwig, R., Fischer, G., Roson, R., and Zografos, C., (2014), Interdisciplinary assessment of sealevel rise and climate change impacts on the lower Nile delta, Egypt, Science of the Total Environment, Vo. 503, pp. 279-288, doi: 10.1016/j.scitotenv.2014.06.111.

positive feedback relationships to further local development opportunities. The modelling undertook analysis of the potential impacts of climate change, changes to Nile flows, and changes in domestic and industrial water demand. The impact of SLR on water, economic and food security is directly modelled. Detailed descriptions of the model development, structure, data and assumptions, results and analysis can be found in Sušnik et al. (2013). Briefly, the integrated systems model was run at a monthly timestep from 2010 to 2050 . For every timestep the water sources, water demands, water balance, crop water requirements, food production (for nine crop types), revenue from agriculture and land loss due to SLR were calculated from model rules. Here, only those results pertinent to SLR impacts and altering cropping patterns are reported from the wider study.

Land subsidence means that the sea surface is rising relative to the land at a rate currently at about $2 \mathrm{~mm} \mathrm{yr}^{-1}$ (0.08 m by 2050; El-Raey et al., 1999; OECD, 2004). Due to uncertainties surrounding the magnitude of additional SLR resulting from thermal expansion and ice-melt, the impacts on Rosetta water resources and food production resulting from SLR in the range $0.1-0.5 \mathrm{~m}$ to 2050 was tested. The amount of SLR was converted to a proportion of land loss through a regression relationship given by El-Raey et al. (1999). During the SLR tests in the systems model, all other model parameters were held at baseline levels (Sušnik et al. 2013), allowing for the isolation and assessment of the impact of SLR to the agricultural sector and the local water balance.

In addition to the SLR tests, a suite of 'what-if' scenarios were simulated assessing the impact to the water balance, crop yield and revenue as a result of altering the current cropping pattern to different degrees. Of the nine crops that were included in the model, changes were made to four. The current area planted with rice, a water-intensive crop, was replaced with different proportions of cotton, vegetables and wheat, depending on the scenario. In the extreme case, all the rice was replaced with the other three crops. It 
To be cited as: Sušnik, J., Vamvakeridou-Lyroudia, L.S., Gebert, N., Kloos, J., Renaud, F. La Jeunesse, I., Mabrouk, B., D.A. Savić, Kapelan, Z. Ludwig, R., Fischer, G., Roson, R., and Zografos, C., (2014), Interdisciplinary assessment of sealevel rise and climate change impacts on the lower Nile delta, Egypt, Science of the Total Environment, Vo. 503, pp. 279-288, doi: 10.1016/j.scitotenv.2014.06.111.

is important to note that total cropped area did not change (except for reductions due to SLR), only the relative proportions of different crops changed. Full details of the cropping scenarios are given in Sušnik et al. (2013).

Modelling suggested that the water resource is currently over-exploited, but this can be alleviated through a suite of complementary policy measures aimed at reducing demand (Sušnik et al., 2013). More specifically, results for SLR simulations (Figure 5) show that as the total amount of SLR increases, the amount of agricultural land loss increases to a maximum of $13 \%$ loss at $0.5 \mathrm{~m}$ SLR. This has both positive and negative impacts. On the positive side, because there is less agricultural production and therefore lower crop water requirements, overall water demand decreases, easing the pressure on the water resource and the local long-term water balance (Figure 5) and maintaining water quality. However, the reduction in agricultural output also translates into local food yield and economic output declines, and as a result, land losses are seen as a net negative impact for the region, with potentially serious implications for food security, economic development and the ability to engage in international trade. Many local citizens are engaged in agriculture, and as such loss of income from this sector could impact their ability to own a home or relocate due to SLR impacts (Section 4). At the local/regional level, the costs of defending this rich agricultural land from SLR must be weighed against the benefits of securing agricultural jobs and income in the area.

Cropping pattern simulations showed interesting results (Figure 6). The general trend is that as more of the current agricultural area planted with rice is replaced with cotton, vegetables and wheat, the overall water balance improves as crop water requirements drop, the local crop yield increases and the local economic output from agriculture increases relative to the present situation (Figure 6). The potential implications are important. It is suggested that by replacing one type of crop with others that are currently being grown, farmers could improve their livelihoods and contribute to an improvement in 
To be cited as: Sušnik, J., Vamvakeridou-Lyroudia, L.S., Gebert, N., Kloos, J., Renaud, F. La Jeunesse, I., Mabrouk, B., D.A. Savić, Kapelan, Z. Ludwig, R., Fischer, G., Roson, R., and Zografos, C., (2014), Interdisciplinary assessment of sealevel rise and climate change impacts on the lower Nile delta, Egypt, Science of the Total Environment, Vo. 503, pp. 279-288, doi: 10.1016/j.scitotenv.2014.06.111.

the local economy due to the potential for enhanced trade. At the same time, is it possible that pressure would be reduced on the water supply, maintaining quantity and quality, potentially helping to mitigate against adverse climate impacts and SLR, essentially acting as an insurance option.

\section{Anticipating vulnerabilities in the course of preventative resettlement in the face of SLR}

The CLICO case study in Alexandria focuses on exploring and anticipating new vulnerabilities and security concerns evolving from an adaptation scenario of large scale preventative resettlement, the potentially only viable response to SLR in the Greater Alexandria region, where $35 \%$ of its densely populated area resides below sea-level. Exposed households' preferred and required employment opportunities and housing conditions were identified and by anticipating the future socio-economic and institutional framework conditions that may restrict their provision, subsequent security concerns were highlighted. The following assessment steps were carried out:

(1) Assessing the conditions that deem coastal areas uninhabitable by exploring the drivers and processes that increase the exposure of Greater Alexandria to SLR. Based on past developments, trends in urbanisation and their spatial directions were overlaid with the spatial entities most likely affected by SLR.

(2) Identification of vulnerable groups and the conditions/factors that increase the likelihood of displacement. Poor households may be trapped in unsafe conditions (i.e. lack the capacity to migrate) and some may refuse to participate in resettlement programs.

(3) Exploring vulnerable groups' adaptive capacity to attain sustainable livelihoods in the community formation phase of resettlement. The focus is on whether employment and housing security can be attained given household employment 
To be cited as: Sušnik, J., Vamvakeridou-Lyroudia, L.S., Gebert, N., Kloos, J., Renaud, F. La Jeunesse, I., Mabrouk, B., D.A. Savić, Kapelan, Z. Ludwig, R., Fischer, G., Roson, R., and Zografos, C., (2014), Interdisciplinary assessment of sealevel rise and climate change impacts on the lower Nile delta, Egypt, Science of the Total Environment, Vo. 503, pp. 279-288, doi: 10.1016/j.scitotenv.2014.06.111.

and housing profiles as well as their preferences for resettlement compared with macro trends in these sectors shaping vulnerable groups' access to income and housing security.

Methods applied were based on: (1) secondary data such as geo-spatial data, SLR projections, socio-economic statistics, urban development reports to estimate future exposure and socio-economic conditions; (2) primary data generated by a household survey (500 samples) to assess exposed households' adaptive capacity and their anticipated resettlement behavior. A "choice experiment" (a research method to mimic peoples' choices and identify their preferences) was applied to understand people's resettlement preferences and willingness to participate in hypothetical resettlement programs. This work is detailed further in Gebert et al. (2013).

Results of the household survey conducted show that large parts of the densely populated delta have limited capacity to migrate. Complicating this, results show that up to $20 \%$ would refuse to voluntarily participate in a governmental resettlement program (Figure 7). As a result of becoming "trapped" in unsafe and/or uninhabitable places, Alexandria would face a significant amount of Internally Displaced People (IDPs) which would have to be accommodated in the delta region. Moreover, if resettlement programs are implemented that are not designed and tailored according to peoples' preferences and requirements, especially regarding the lack of adequate housing and income opportunities, people may be forced to live in informal settings, which could result in livelihood deprivation and, potentially, displacement and conflict. From the work in CLIMB and WASSERMed, it is apparent how a combination of climate, hydrological, and social change could bring about those drivers that result in either forced or planned resettlement, and provisions should be made in advance if such a situation arises. CLICO has also highlighted the utility of assessing future exposure (for example using point 1 
To be cited as: Sušnik, J., Vamvakeridou-Lyroudia, L.S., Gebert, N., Kloos, J., Renaud, F. La Jeunesse, I., Mabrouk, B., D.A. Savić, Kapelan, Z. Ludwig, R., Fischer, G., Roson, R., and Zografos, C., (2014), Interdisciplinary assessment of sealevel rise and climate change impacts on the lower Nile delta, Egypt, Science of the Total Environment, Vo. 503, pp. 279-288, doi: 10.1016/j.scitotenv.2014.06.111.

above) in combining the role of climate and social drivers for estimating the potential impacts on security and vulnerability in an area.

In particular, when considering the prospects and future vulnerabilities as a consequence of preventive resettlement, 'income' and 'housing' security were identified as critical factors. With respect to income security, farming and fishing households are especially vulnerable, potentially facing long-term unemployment when aiming to re-enter their former employment market in the course of resettlement. There are a number of factors that drive this trend, but the two main factors are: (1) farmers' loss of productive agricultural land due to SLR (which could also impact on revenue generated, see results from Section 3), potentially up to $13 \%$ (ECRI, Pers. Comm.), the potential loss of agricultural land due to the rise of informal settlements and the continuous decline of the agricultural sector and employment market as a consequence of increasing land scarcity (land degradation, urbanisation, land loss due to SLR); and (2) the lack of farmers' and their household members' flexibility to engage in other income opportunities, due largely to homogeneous household employment profiles in farming.

For housing security, the situation in Egypt is paradoxical. Whereas oversupply exists for high-end housing, housing shortage is severe for low and middle income segments. Twelve to fifteen million people in Egypt have inadequate access to housing (Jacobs and Hossam, 2008). In Alexandria, $40 \%$ of the population lives in squatter settlements (World Bank: GOPP, 2008). In addition, the rental market is small and inflexible. Due to a law granting lifetime tenant protection, owners have little means to acquire personal use of their owned properties. Moreover, legally fixed low rental prices at the level of the 1950s and high construction costs provide little incentive for the expansion and development of a housing market for low and middle income groups. Taking SLR in Alexandria into account, the absence of a rental and real estate market for affordable housing may give rise to more informal settlements in the future. Thus, policies to enhance the development 
To be cited as: Sušnik, J., Vamvakeridou-Lyroudia, L.S., Gebert, N., Kloos, J., Renaud, F. La Jeunesse, I., Mabrouk, B., D.A. Savić, Kapelan, Z. Ludwig, R., Fischer, G., Roson, R., and Zografos, C., (2014), Interdisciplinary assessment of sealevel rise and climate change impacts on the lower Nile delta, Egypt, Science of the Total Environment, Vo. 503, pp. 279-288, doi: 10.1016/j.scitotenv.2014.06.111.

of an affordable housing market should include liberalisation of the tenancy law, including the cancelation of dismissal protection and fixed rent prices as well as ensuring access to the development of a housing credit market system for a larger segment of the population. Moreover, subvention policies and incentives are needed that allow for the realization of publicly and privately invested affordable housing projects (Jacobs and Hossam 2008).

\section{Summary of project results: the need to avoid silo thinking}

This section briefly summarises the results from the three projects. It shows that each project is dealing with complex and important issues that merit their own spotlight, while demonstrating that each project could easily be viewed in isolation, depriving the opportunity for a glimpse of the bigger, integrated, picture (Section 6).

CLIMB estimated total ground water extraction, helping to place local limits on safe extraction yields with respect to maintaining building and infrastructure safety. Large scale measurements of surface displacement were used to identify areas of interest for small scale hydrological monitoring. By enhancing model validation, the reduction of uncertainty and risk quantification was investigated. Risk assessment was performed in close collaboration with local and regional stakeholders in the final stages of the project, and delivered useful information for adaptive urban planning and robust infrastructure development in response to the threats of SLR and groundwater pumping. Stakeholder interaction underlined the difficulty of water users in identifying the diversity of water uses and many stakeholders highlighted the need for better integration of farmers in the water management decision process. Other stakeholders, during the CLIWASEC final conference in Brussels (November 2013), expressed the importance in pursuing dissemination of project results to further increase awareness of the impacts of climate change on SLR, hydrology and infrastructures in the region and support, where needed, 
To be cited as: Sušnik, J., Vamvakeridou-Lyroudia, L.S., Gebert, N., Kloos, J., Renaud, F. La Jeunesse, I., Mabrouk, B., D.A. Savić, Kapelan, Z. Ludwig, R., Fischer, G., Roson, R., and Zografos, C., (2014), Interdisciplinary assessment of sealevel rise and climate change impacts on the lower Nile delta, Egypt, Science of the Total Environment, Vo. 503, pp. 279-288, doi: 10.1016/j.scitotenv.2014.06.111.

local relocation. CLIMB results were disseminated to water management bodies and local water users through local workshops lead by CLIMB's Egyptian case study leader. One important finding was to reveal how strongly water users rely on water coming from desalination for supply. However, costs for desalination plants and for water transportation make this water resource expensive (Boyé, 2008). . Even if desalination had started 100 years ago in Egypt, the water volume coming from desalination would reach only 100 million $\mathrm{m}^{3}$, concentrated in the Red Sea coastal areas. Energy requirements and technologic knowledge would be limiting factors (Reham et al., 2007).

The potential impact of SLR, while not directly affecting in a negative way water supply, would be detrimental to both food security and local economy as shown by WASSERMed. Through the reduction of high-quality agricultural land, farmers could be forced to scale back operations, relocate operations or find new ways of improving crop yield and/or economic revenue, for example by altering cropping patterns and possibly in exploiting international trade. If such gains cannot be met, farmers and their families may be forced to relocate, which, as shown in CLICO, has its own complex issues. There is a fine balance between the cost of defending against SLR, and the benefits that this would have to offer in terms of continuation of the dominant agricultural activity, the preservation of the local water balance and economy, and the ability for families to remain in place.

Assessing potential security concerns arising from the challenges posed by the resettlement of communities due to future SLR is important in order to raise awareness of these concerns and challenges in Alexandria as shown in CLICO. It would play an important role in providing decision-making support to governments and urban planners when incorporating SLR and resettlement planning into policy. Incentive-based resettlement programs tailored to people's requirements are needed to reduce potential conflicts which might arise resulting from non-participation in and the mismanagement of resettlement programs. Policies dealing with climate change and SLR should include risk 
To be cited as: Sušnik, J., Vamvakeridou-Lyroudia, L.S., Gebert, N., Kloos, J., Renaud, F. La Jeunesse, I., Mabrouk, B., D.A. Savić, Kapelan, Z. Ludwig, R., Fischer, G., Roson, R., and Zografos, C., (2014), Interdisciplinary assessment of sealevel rise and climate change impacts on the lower Nile delta, Egypt, Science of the Total Environment, Vo. 503, pp. 279-288, doi: 10.1016/j.scitotenv.2014.06.111.

based land use policy, and focus on transformations in employment structures away from agriculture and fishing. The identification of resettlement sites in advance, vocational training, the creation of employment and opportunities in various employment sectors, and the provision of socially acceptable housing would be of great benefit with regard to increasing participation in and the sustainability of planned resettlement programs.

\section{Synthesis: towards interdisciplinary research}

The three projects joined together (Figure 2) to identify and foster scientific synergies and to establish a more focused and efficient policy outreach strategy. Major building blocks of this collaboration included scientific exchange and review, identification and utilization of complementary monitoring and modeling methods, harmonization and data sharing and discussion of dissemination strategies. The projects hosted joint annual meetings, thus creating a joint dissemination plan for presenting the project results, and set-up a project web-portal to host and advertise further related projects. During the concluding conference, the projects presented a joint 'Summary for Policymakers' (2013). The dissemination of research results continues to date at scientific conferences and through network meetings with stakeholders.

An important conclusion from the CLIWASEC cluster is that the results from the three projects show that the different avenues of research, while diverse, address closely related issues that affect each other. The complex interweaving of many disparate aspects can be highlighted by clustering complementary projects such as those in CLIWASEC. Here, the impacts of sea-level rise were studied independently by three different projects with three different aims, but with a common driver and study area. Through the CLIWASEC cluster, we have an opportunity to explore these connections, and understand how SLR affects many processes, moving away from silo-thinking. This complexity is illustrated below. 
To be cited as: Sušnik, J., Vamvakeridou-Lyroudia, L.S., Gebert, N., Kloos, J., Renaud, F. La Jeunesse, I., Mabrouk, B., D.A. Savić, Kapelan, Z. Ludwig, R., Fischer, G., Roson, R., and Zografos, C., (2014), Interdisciplinary assessment of sealevel rise and climate change impacts on the lower Nile delta, Egypt, Science of the Total Environment, Vo. 503, pp. 279-288, doi: 10.1016/j.scitotenv.2014.06.111.

WASSERMed has shown that SLR of $0.5 \mathrm{~m}$ could contribute up to $13 \%$ land loss, possibly leading to issues surrounding food availability and security which go beyond the scope of this paper. In addition, the water resource is being over-exploited. Altering cropping patterns, and potentially further exploiting international trade, could compensate for some land loss and mitigate resource over-exploitation (Figure 5 and Sušnik et al., 2013). Population, socio-economic changes, and expanding agriculture could further stress water resources, with local populations possibly resorting to acquiring more water through groundwater. If groundwater pumping increases and if seawater intrusion continues, CLIMB has shown that there is potential for increased damage to infrastructure, particularly in cities such as Alexandria, which is already experiencing problems, as well as increased saltwater instrusion These effects could exacerbate those impacts suggested in WASSERMed. Resulting from less available land of poorer quality, a more scarce water resource, and a reduction in safe housing stock, the work from CLICO suggests that there may be considerable implications for: a) the dominant agricultural employment sectors and; b) housing issues and relocation. If agricultural land is lost, there is the potential for widespread unemployment, particularly due to 'the lack of farmers' and their household members' flexibility to engage in other income opportunities, due largely to homogeneous household employment profiles in farming' (Section 4). This, coupled with the potential for loss of suitable accommodation for low- to middle-income families due to land subsidence, could result in 'forced relocation'. With reduced income opportunities, families could become 'trapped' in unfavourable conditions. This situation could be exacerbated by current institutional frameworks relating to housing and rental market. All these issues combine to have potentially serious implications for local development.

As shown in Section 5, it would be easy to isolate the projects' research, itself a formidable task, especially when the myriad uncertainties associated with each subject 
To be cited as: Sušnik, J., Vamvakeridou-Lyroudia, L.S., Gebert, N., Kloos, J., Renaud, F. La Jeunesse, I., Mabrouk, B., D.A. Savić, Kapelan, Z. Ludwig, R., Fischer, G., Roson, R., and Zografos, C., (2014), Interdisciplinary assessment of sealevel rise and climate change impacts on the lower Nile delta, Egypt, Science of the Total Environment, Vo. 503, pp. 279-288, doi: 10.1016/j.scitotenv.2014.06.111.

are considered. However, through the exploration of the interconnected issues resulting from SLR, it is shown that when taken together, project clustering has added richness to the individual results. Impacts related to land loss, a declining water balance, reduced farming opportunities due to water and soil degradation and damage to infrastructure all contribute to possible social-economic problems that could manifest in ways such as unemployment, food and water shortages, reduced opportunities to re-engage in employment and housing shortages, and lead to positive feedbacks that aggravate the situation. Despite this, some impacts have not been addressed. For example, how might SLR impact on local and regional governance? What are the possible impacts on wider social structures? How might the local and regional economy change as a result? While these questions were beyond the scope of CLIWASEC, they form potential useful future lines of research.

This integrated analysis shows how carefully policy-makers must consider all possible impacts, even if some of these are not immediately obvious, and recognise that a) some impacts may be missed and; b) that some drivers will probably be neglected. This paper has focused on SLR, without considering changes to regional precipitation predictions, changes to Nile flow volumes, to average temperatures, socio-demographic evolution and so forth, all of which adds yet more complexity. This does not detract from our message that holistic, integrated assessment of impacts, gleaned through the clustering and multidisciplinary collaboration of thematically related projects, is required by scientists and policy-makers. Research can provide the analysis framework and results which may then be used in policy-making to help shape important decisions accounting more fully for inter-related impacts. If results and implications are delivered and analysed in fragmented, unrelated 'silos', important connections may be missed. CLIWASEC has illustrated the benefit of examining inter-related issues in an integrated way. 
To be cited as: Sušnik, J., Vamvakeridou-Lyroudia, L.S., Gebert, N., Kloos, J., Renaud, F. La Jeunesse, I., Mabrouk, B., D.A. Savić, Kapelan, Z. Ludwig, R., Fischer, G., Roson, R., and Zografos, C., (2014), Interdisciplinary assessment of sealevel rise and climate change impacts on the lower Nile delta, Egypt, Science of the Total Environment, Vo. 503, pp. 279-288, doi: 10.1016/j.scitotenv.2014.06.111.

Despite the promise of clustering shown by CLIWASEC, there is room for improvement in future clustering activities. The projects were clustered after formal, separate, approval of the individual projects, and were clustered on the common study area (i.e., forming a multidisciplinary approach to a common problem; Quevauviller et al., 2012). For the first year of the clustering, relatively little interaction occurred between projects. At an annual CLIWASEC cluster meeting at the end of the first year of the projects, it was agreed to focus on SLR in the Nile delta as the common theme and to agree on common project activities, defining the transition from the multidisciplinary research of Quevauviller et al. (2012) to more interdisciplinary assessment of issues. Still, genuine interdisciplinarity was not achieved. Improvements such as agreeing case study sites and common research activities between projects should be agreed before project outset, and is being addressed in the new Horizon2020 Programme. In this way, communication between parties is established prior to project initiation, and the common ground is laid for research and sharing of results and data. This would lead to more effective interdisciplinary research into complex issues with more robust findings and policy messages, something that is being called for ever more often. The key points from our analysis of this clustering can be summarised as:

- Clustering should occur right after project approval, with potentially clustered projects aligning their aims to more closely match each other;

- Time and resources should be explicitly invested into clustering, as for example extra resources for pursuing interdisciplinary integration and perhaps after the end of the projects.

- More integrated analysis of results leads to a better understanding of the 'bigger picture' surrounding complex issues, meaning policy makers have a deeper understanding of social-ecological systems; 
- Clustering adds richness to individual project results, and provides additional opportunities for researchers to work beyond academic silos;

- Where possible, clustering is recommended for future research, particularly as it offers a clear route towards truly interdisciplinary research.

This paper shows the importance of effectively clustering related projects and comparing and analysing results in a common framework, and fulfils some of the potential set out in Ludwig et al. (2011). While this is a good start, goes beyond mutlidisciplinary research, and represents a step in the right direction, it still falls short of genuine 'interdisciplinary' research. The work in CLIWASEC for the Nile is far more integrated than the originally expected multi-disciplinary and multi-project independent studies for the same region, with sea level rise analysis providing a common research objective. The CLIWASEC cluster of projects shows that such interaction between disciplines can add considerable richness to results, with consequent improvements in impact assessment resulting from environmental and social change. Holistic results in turn will guide policy-makers and shape EU policy (Quevauviller et al., 2012), which must deal with many complex issues simultaneously. It is hoped that such clusters continue into the future, build on the lessons learnt through CLIWASEC, and that they lead the way towards integrated interdisciplinary research.

\section{Acknowledgements}

The three projects in this paper were funded by the European Commission Seventh Framework Program (CLICO, Grant Number: 244443; CLIMB, Grant Number: 244151; WASSERMed, Grant Number: 244255). We gratefully acknowledge all project partners and stakeholders who participated in and contributed to these studies. We thank three anonymous reviewers for their valuable comments which improved this manuscript.

\section{References}


To be cited as: Sušnik, J., Vamvakeridou-Lyroudia, L.S., Gebert, N., Kloos, J., Renaud, F. La Jeunesse, I., Mabrouk, B., D.A. Savić, Kapelan, Z. Ludwig, R., Fischer, G., Roson, R., and Zografos, C., (2014), Interdisciplinary assessment of sealevel rise and climate change impacts on the lower Nile delta, Egypt, Science of the Total Environment, Vo. 503, pp. 279-288, doi: 10.1016/j.scitotenv.2014.06.111.

Berardino, P., Constantini, M., Franceschetti, G., lodice, A., Pietranera, I., Rizzo, V. 2003. Use of differential SAR interferometry in monitoring and modelling large slope instability at Maratea (Basilicata, Italy). Engineering Geology. 68(1-2): 31-51.

Beyene, T., Lettenmaier, D.P., Kabat, P. 2010. Hydrologic impacts of climate change on the Nile River Basin: implications of the 2007 IPCC scenarios. Climate Change. 100: 433461.

Boyé Henry, 2008. Eau, énergie, dessalement et changement climatique en Méditerranée. PNUE, Plan Bleu, 39 p.

Christensen, J. H., Christensen, O. B. 2007. A summary of the PRUDENCE model projections of changes in European climate by the end of this century. Climatic Change. 81, 7-30.

Conway, D. 2005. From headwater tributaries to international river: Observing and adapting to climate variability and change in the Nile basin. Global Environmental Change. 15: 99-114.

Dasgupta, S., Laplante, B., Meisner, C., Yan, J. 2007. The impact of Sea Level Rise on Developing Countries: A Comparative Study. World Bank Policy Research Working Paper 4136.

Dasgupta, S., Laplante, B., Murray, S., Wheeler, D. 2009. Sea-Level Rise and Storm Surges: A Comparative Analysis of Impacts in Developing Countries. World Bank, Policy Research Working Paper 4901.

El-Raey, M. 2010. Impacts and Implications of Climate Change for the Coastal Zones of Egypt. In: Coastal Zones and Climatic Change. Pragmatic Steps for Global Security. (Eds. Michel, D., Pandya, A). The Stimpson Center. pp. 31-50.

El-Raey, M., Dewidar, K., El-Hattab, M. 1999. Adaptation to the impacts of sea-level rise in Egypt. Mitigation and Adaptation Strategies for Global Change. 4: 343-61. 
To be cited as: Sušnik, J., Vamvakeridou-Lyroudia, L.S., Gebert, N., Kloos, J., Renaud, F. La Jeunesse, I., Mabrouk, B., D.A. Savić, Kapelan, Z. Ludwig, R., Fischer, G., Roson, R., and Zografos, C., (2014), Interdisciplinary assessment of sealevel rise and climate change impacts on the lower Nile delta, Egypt, Science of the Total Environment, Vo. 503, pp. 279-288, doi: 10.1016/j.scitotenv.2014.06.111.

El-Sadek, A. 2010. Water desalination: An imperative measure for water security in Egypt. Desalination. 250: 876-884. doi: 10.1016/j.desal.2009.09.143

Ferretti, A., Prati, C., Rocca, F. 1999. Permanent scatterers in SAR interferometry. Proceedings of IEEE International Geoscience and Remote Sensing Symposium, Hamburg, Germany, 28 June-2 July 1999. pp. 1528-1530.

Fitzgerald, D.M., Fenster, M.S. Argow, B.A., Buynevich, I.V. 2010. Coastal Impacts Due to Sea-Level Rise. Annual Review of Earth and Planetary Sciences. 36: 601-647.

Ford, A. 1999. Modelling the Environment: An Introduction to System Dynamics Modeling of Environmental Systems. Island Press, Washington, D.C., U.S.A.

Gebert, N., Kloos, J., Birkmann, J., Rosenfeld, T. 2013. Preventive Resettlement, Urban Development and Consequences for Future Vulnerability in Alexandria, Egypt - Case Study on Livelihood Security to Future Sea Level Rise. Submitted to International Journal of Disaster Risk Reduction.

Gehad, A. 2003. Deteriorated Soils in Egypt: Management and Rehabilitation. Ministry of Agriculture and Land Reclamation. Executive Authority for Land Improvement Projects (EALIP). 37pp.

Giannakopoulos, C., Le Sagar, P., Bindi, M., Moriondo, M., Kostopoulou, E., Goodess, C. M. 2009. Climatic changesand associated impacts in the Mediterranean resulting from a $2^{\circ} \mathrm{C}$ global warming. Global Planetary Change. 68, 209-224.

Gohar, A.A., Ward, F.A. 2010. Gains from expanded water irrigation trading in Egypt: An integrated basin approach. Ecological Economics. 69: 2535-2548. doi:

10.1016/ecolecon.2010.07.030

IPCC, 2013: Climate Change 2013: The Physical Science Basis. Contribution of Working Group I to the Fifth Assessment Report of the Intergovernmental Panel on Climate 
To be cited as: Sušnik, J., Vamvakeridou-Lyroudia, L.S., Gebert, N., Kloos, J., Renaud, F. La Jeunesse, I., Mabrouk, B., D.A. Savić, Kapelan, Z. Ludwig, R., Fischer, G., Roson, R., and Zografos, C., (2014), Interdisciplinary assessment of sealevel rise and climate change impacts on the lower Nile delta, Egypt, Science of the Total Environment, Vo. 503, pp. 279-288, doi: 10.1016/j.scitotenv.2014.06.111.

Change [Stocker, T.F., D. Qin, G.-K. Plattner, M. Tignor, S.K. Allen, J. Boschung, A. Nauels, Y. Xia, V. Bex and P.M. Midgley (eds.)]. Cambridge University Press, Cambridge, United Kingdom and New York, NY, USA, 1535 pp.

IWTC, 2011. Fifteenth International Water Technology Conference, Alexandria, CLIMB Stakeholder Meeting Workshop. http://iwtc.info/archive/iwtc-2011/.

Jacobs, A., Hossam, M. 2008. Auf Sand gebaut: die ägyptische Wohnungsnot und ihre Folgen. Available online at http://www.kas.de/wf/doc/kas_14834-544-1-30.pdf. Last accessed 24/04/2012.

Kingston, D.G., Taylor, R.G. 2010 Sources of uncertainty in climate change impacts on river discharge and groundwater in a headland catchment of the Upper Nile Basin, Uganda. Hydrology and Earth System Science. 14: 1297-1308.

Kotb, T.H.S., Watanabe, T., Ogino, Y., Tanji, K.K. 2000. Soil salinisation in the Nile Delta and related policy issues in Egypt. Agricultural Water Management. 43: 239-261. Laukens, T.R., Piyush Shanker, A., Dehls, J.F., Zebker, H.A., Henderson, I.H.C., Larsen, Y. 2010. Detailed rockslide mapping in northern Norway with small baseline and persistent scatter interfermetric SAR time series methods. Remote Sensing of the Environment. 114(9): 2097-2109.

Ludwig, R., Roson, R., Zografos, C., Kallis, G. 2011. Towards an inter-disciplinary research agenda on climate change, water and security in southern Europe and neighbouring countries. Environmental Science and Policy. 14: 794-803

Mohamed, S., Mohsen, M., Adel, H. 2008. Egyptian Collapsible Soils and their Improvement. GeoCongress 2008 - Geosustainability and Geohazard Mitigation. ACSE, 654-661. 
To be cited as: Sušnik, J., Vamvakeridou-Lyroudia, L.S., Gebert, N., Kloos, J., Renaud, F. La Jeunesse, I., Mabrouk, B., D.A. Savić, Kapelan, Z. Ludwig, R., Fischer, G., Roson, R., and Zografos, C., (2014), Interdisciplinary assessment of sealevel rise and climate change impacts on the lower Nile delta, Egypt, Science of the Total Environment, Vo. 503, pp. 279-288, doi: 10.1016/j.scitotenv.2014.06.111.

Organisation for Economic Co-operation and Development (OECD). 2004. Development and Climate Change in Egypt: Focus on coastal resources and the Nile. Environment Directorate, Environmental Policy Committee. 68pp.

Quevauviller, P., Barceló, D., Beniston, M., Djordjevic, S., Harding, R.J., Iglesias, A., Ludwig, R., Navarra, A., Navarro Ortega, A., Mark, O., Roson, R., Sempere, D., Stoffel, M., van Lanen, H.A.J. and Werner, M. 2012. Integration of research advances in modelling and monitoring in support of WFD river basin management planning in the context of climate change, Science of the Total Environment. 440: 166-177.

Reham M. Y., Mostafa L.S., Abeer F.S. 2007. Desalination Technology, Roadmap 2030. National Egyptian Information and Decision Support System Center, Center for Future Studies, 61 p. http://www.idsc.gov.eg

Shaban M., Urban, B., El Saadi A., Faisal, M. 2010. Detection and mapping of water pollution variation in the Nile Delta using multivariate clustering and GIS techniques. Journal of Environmental Management. 91: 1785-1793. doi:

10.1016/j.envman.2010.03.020

Sušnik J., Vamvakeridou-Lyroudia L.S., Savić D.A., Kapelan Z. 2012. Integrated System Dynamics Modelling for water scarcity assessment: Case study of the Kariouan region. Science of the Total Environment. 440: 290-306. doi: 10.1016/j.scitotenv.2012.050.085.

Sušnik J., Vamvakeridou-Lyroudia L.S., Savić D.A., Kapelan Z. 2013. Integrated modelling of the water-agricultural system in the Rosetta region, Nile delta, Egypt, using system dynamics. Journal of Water and Climate Change. 4(3): 209-231. doi: 10.2166/wcc.2013.069. 
To be cited as: Sušnik, J., Vamvakeridou-Lyroudia, L.S., Gebert, N., Kloos, J., Renaud, F. La Jeunesse, I., Mabrouk, B., D.A. Savić, Kapelan, Z. Ludwig, R., Fischer, G., Roson, R., and Zografos, C., (2014), Interdisciplinary assessment of sealevel rise and climate change impacts on the lower Nile delta, Egypt, Science of the Total Environment, Vo. 503, pp. 279-288, doi: 10.1016/j.scitotenv.2014.06.111.

Werner, C., Wegmuller, U., Strozzi, T., Wiesmann, A. 2003. Interferometric point target analysis for deformation mapping. Proceedings of IEEE International Geoscience and Remote Sensing Symposium, 21-25 July, 2003. pp. 4362-4364.

World Bank; General Organization for Physical Planning. 2008. Alexandria City Development Strategy. Moving from Vision to Strategy and Implementation. Process and Results 2004 - 2008. Available at http://siteresources.worldbank.org/INTEGYPT/Resources/Documentation_Alexandria_C DS_May_2008-Updated_July.pdf. Last accessed 13/06/2012

Zhang, Y., Zhang, J., Wu, H., Lu, Z., Guangtong, S. 2011. Monitoring of urban subsidence with SAR interferometric point target analysis: A case study in Suzhou, China. International Journal of Applied Earth Observation and Geoinformation. 13(5): 812-818. 
Figure 1: Locations of the 23 case study areas being studied in CLIWASEC projects.

Black circle highlights the common area between all three projects that is the focus of this paper. Boxes indicate study sites for each of the projects.

Figure 2: Interactions between projects

Figure 3: Topographic deformation in the Alexandria Governorate from 2006-2010 by means of Differential SAR-Interferometry. At right, examples of the damage caused in Alexandria due to local land subsidence.

Figure 4: Casual loop diagram (see Ford, 1999 for explanation) showing the main connections in the agricultural sub-system of the WASSERMed Rosetta systems model. '+' symbols represent positive influences/feedbacks (i.e. change in the affected variable is in the same direction as change in the driving variable) while '-' symbols represent negative influences/feedbacks. Dashed arrows represent influencing variables from other sub-systems within the same model. See Sušnik et al. (2013) for a full description of the Rosetta model.

Figure 4: Impact of sea-level rise scenarios on the net cumulative Rosetta water balance. Plot shows the cumulative water balance in the Rosetta study area under different levels of SLR. Sim. $13=0.1 \mathrm{~m}$ SLR, Sim $17=0.5 \mathrm{~m}$ SLR. Sims. $14-16$ increase in increments of $0.1 \mathrm{~m}$ between Sims. 13 and 17. Model timestep units are in months starting in 2010 .

Figure 5: (a) showing the improvement in the local water balance for the end of simulation year 2010 (black bars, left-side axis) and for the end of the simulation year 2049 (grey 
To be cited as: Sušnik, J., Vamvakeridou-Lyroudia, L.S., Gebert, N., Kloos, J., Renaud, F. La Jeunesse, I., Mabrouk, B., D.A. Savić, Kapelan, Z. Ludwig, R., Fischer, G., Roson, R., and Zografos, C., (2014), Interdisciplinary assessment of sealevel rise and climate change impacts on the lower Nile delta, Egypt, Science of the Total Environment, Vo. 503, pp. 279-288, doi: 10.1016/j.scitotenv.2014.06.111.

bars, right-side axis, note scale change) when compared with the current situation. (b) showing the change in crop water requirements and revenue (left-side axis, black bars and grey bars respectively) and crop yield (right-side axis, white bars, note change of scale) at the end of simulation year 2049. More rice is replaced from Simulation 36 to 42 (i.e. from left to right on the $x$-axis).

Figure 6: Willingness among the SLR-affected population of Alexandria to resettle by regional type.

Figure 1

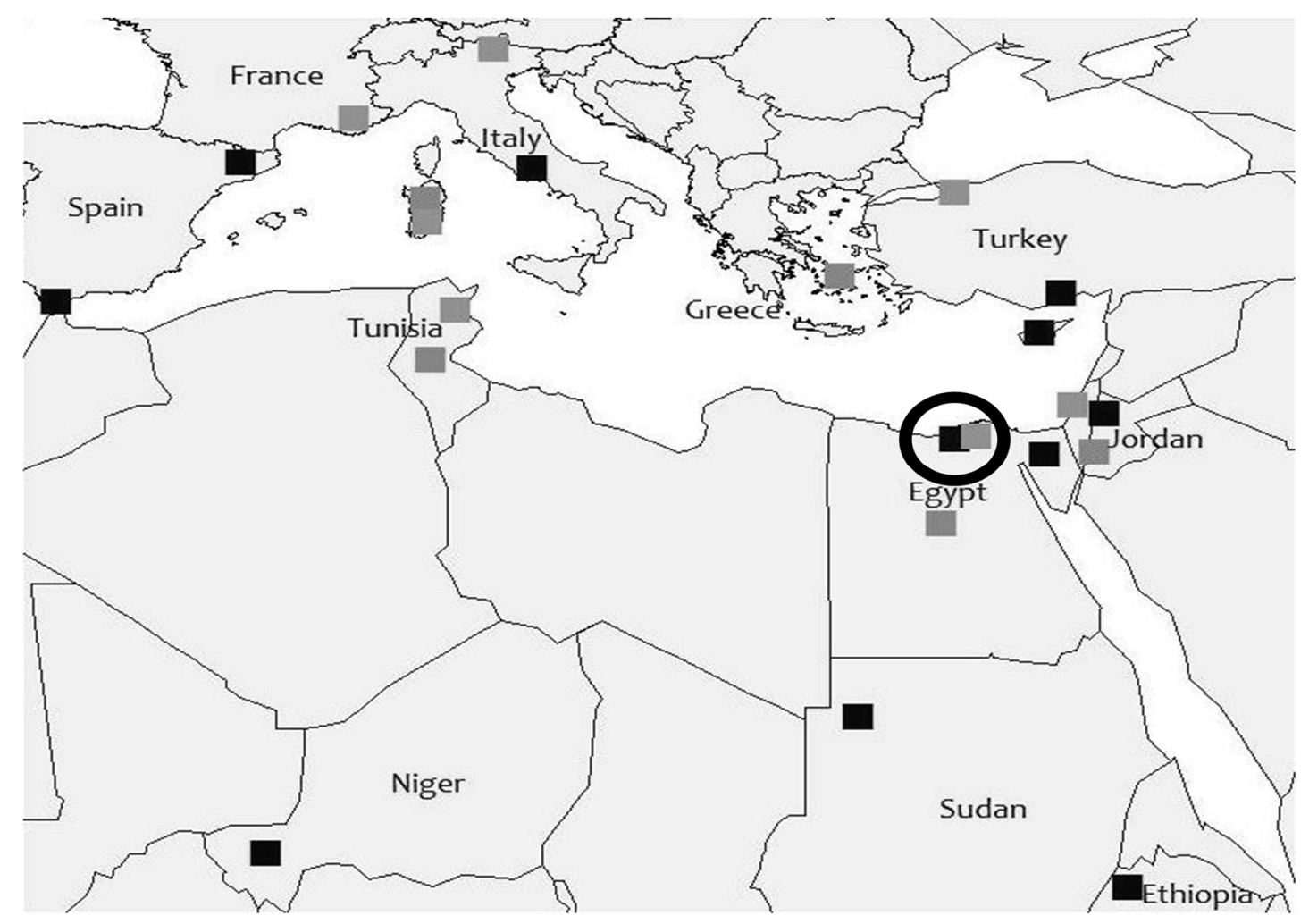


To be cited as: Sušnik, J., Vamvakeridou-Lyroudia, L.S., Gebert, N., Kloos, J., Renaud, F. La Jeunesse, I., Mabrouk, B., D.A. Savić, Kapelan, Z. Ludwig, R., Fischer, G., Roson, R., and Zografos, C., (2014), Interdisciplinary assessment of sealevel rise and climate change impacts on the lower Nile delta, Egypt, Science of the Total Environment, Vo. 503, pp. 279-288, doi: 10.1016/j.scitotenv.2014.06.111.

Figure 2

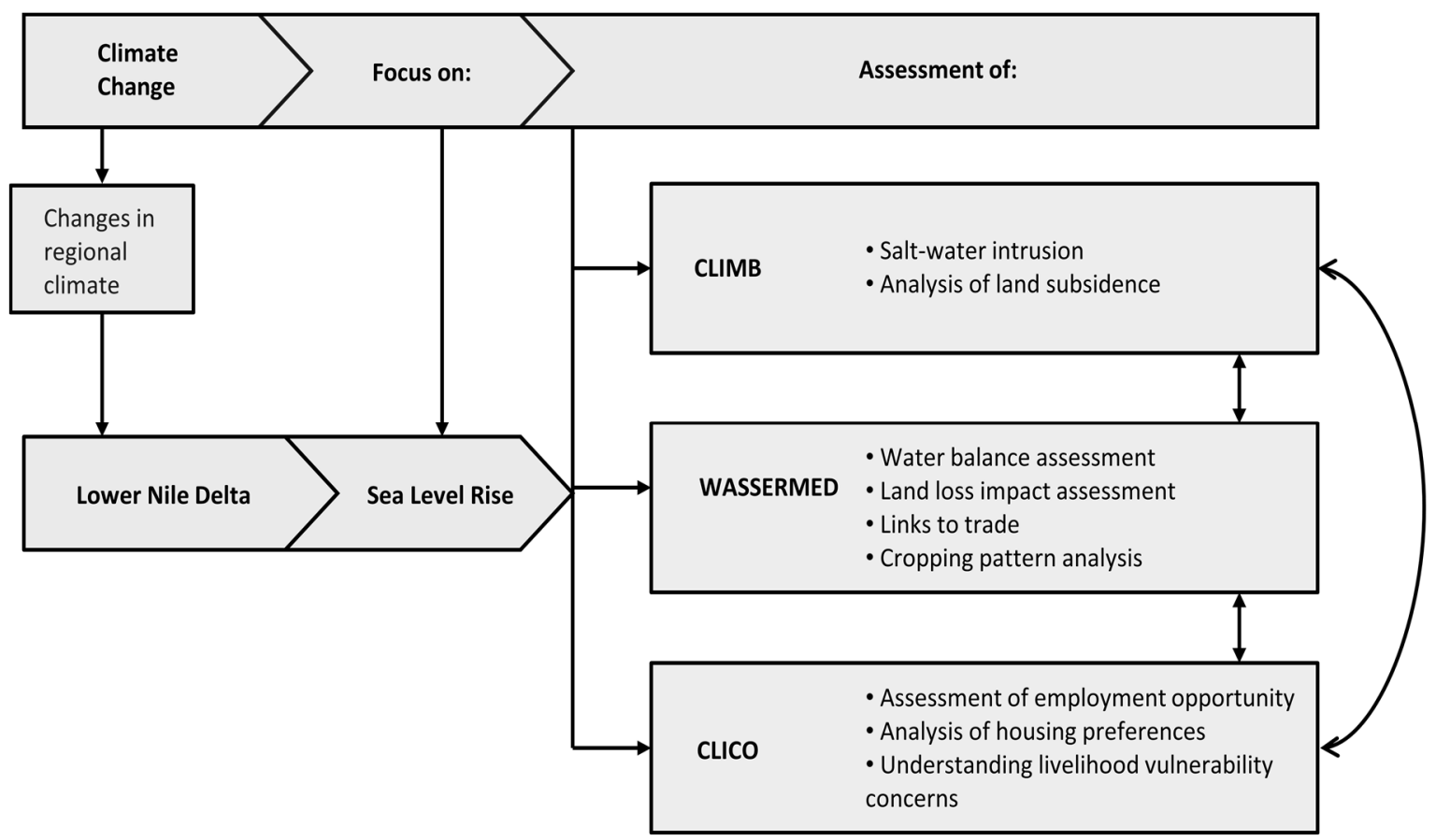

Figure 3
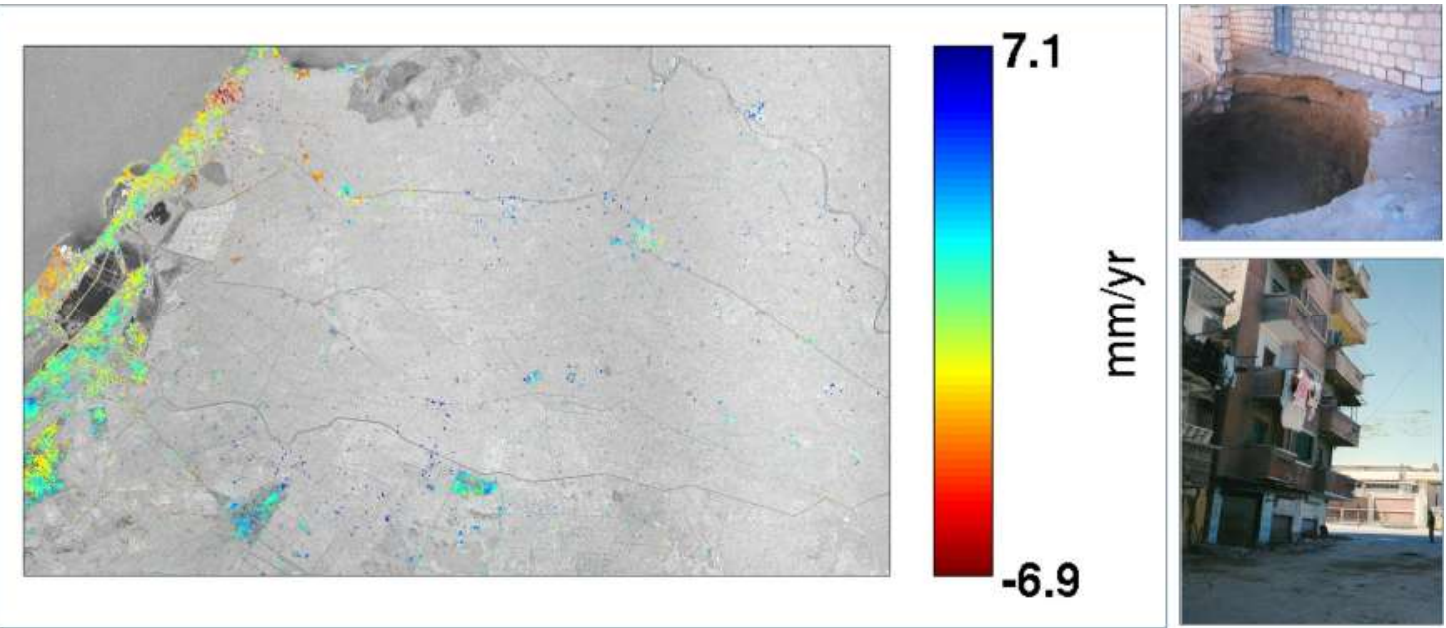
To be cited as: Sušnik, J., Vamvakeridou-Lyroudia, L.S., Gebert, N., Kloos, J., Renaud, F. La Jeunesse, I., Mabrouk, B., D.A. Savić, Kapelan, Z. Ludwig, R., Fischer, G., Roson, R., and Zografos, C., (2014), Interdisciplinary assessment of sealevel rise and climate change impacts on the lower Nile delta, Egypt, Science of the Total Environment, Vo. 503, pp. 279-288, doi: 10.1016/j.scitotenv.2014.06.111.

Figure 4

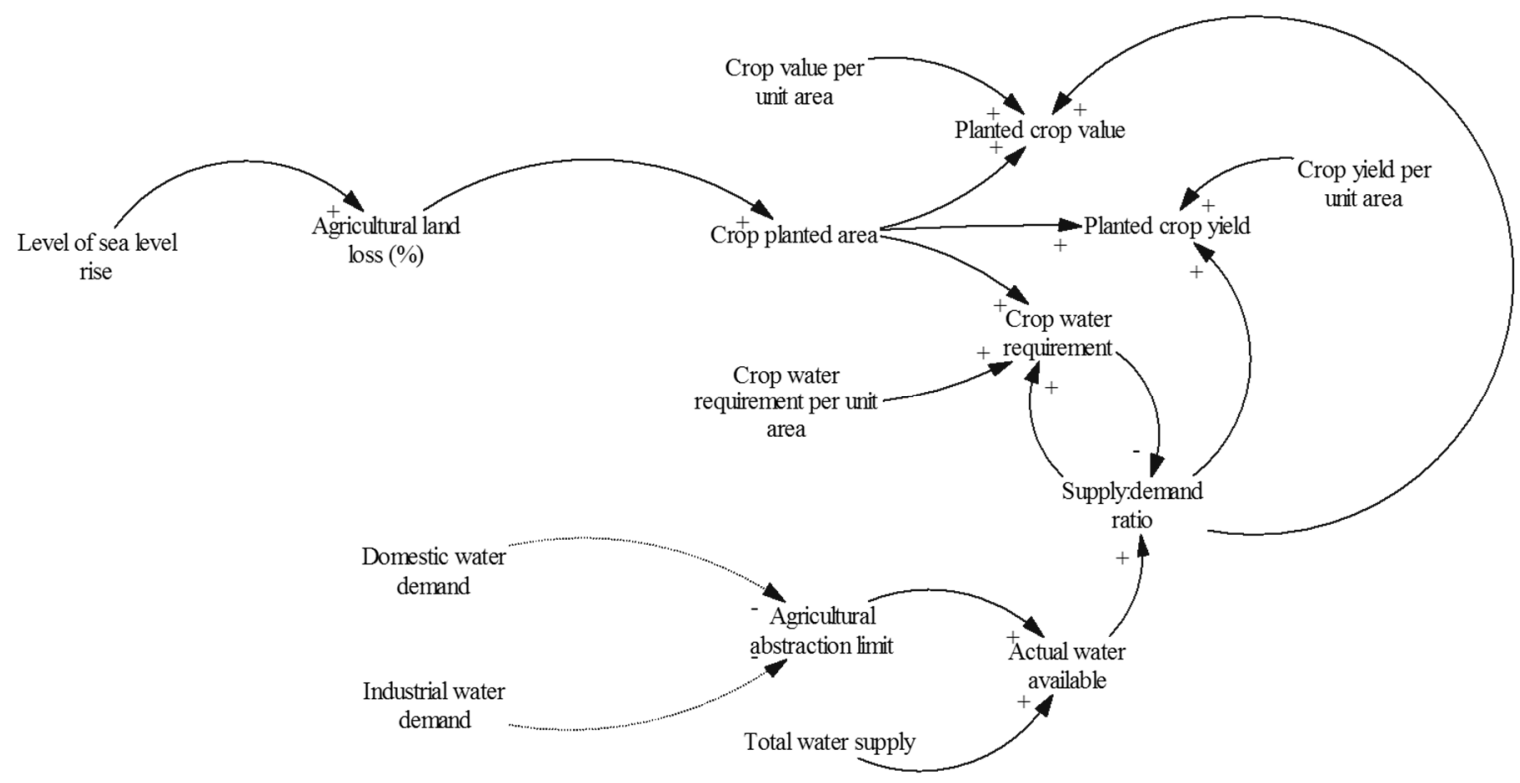

Figure 5

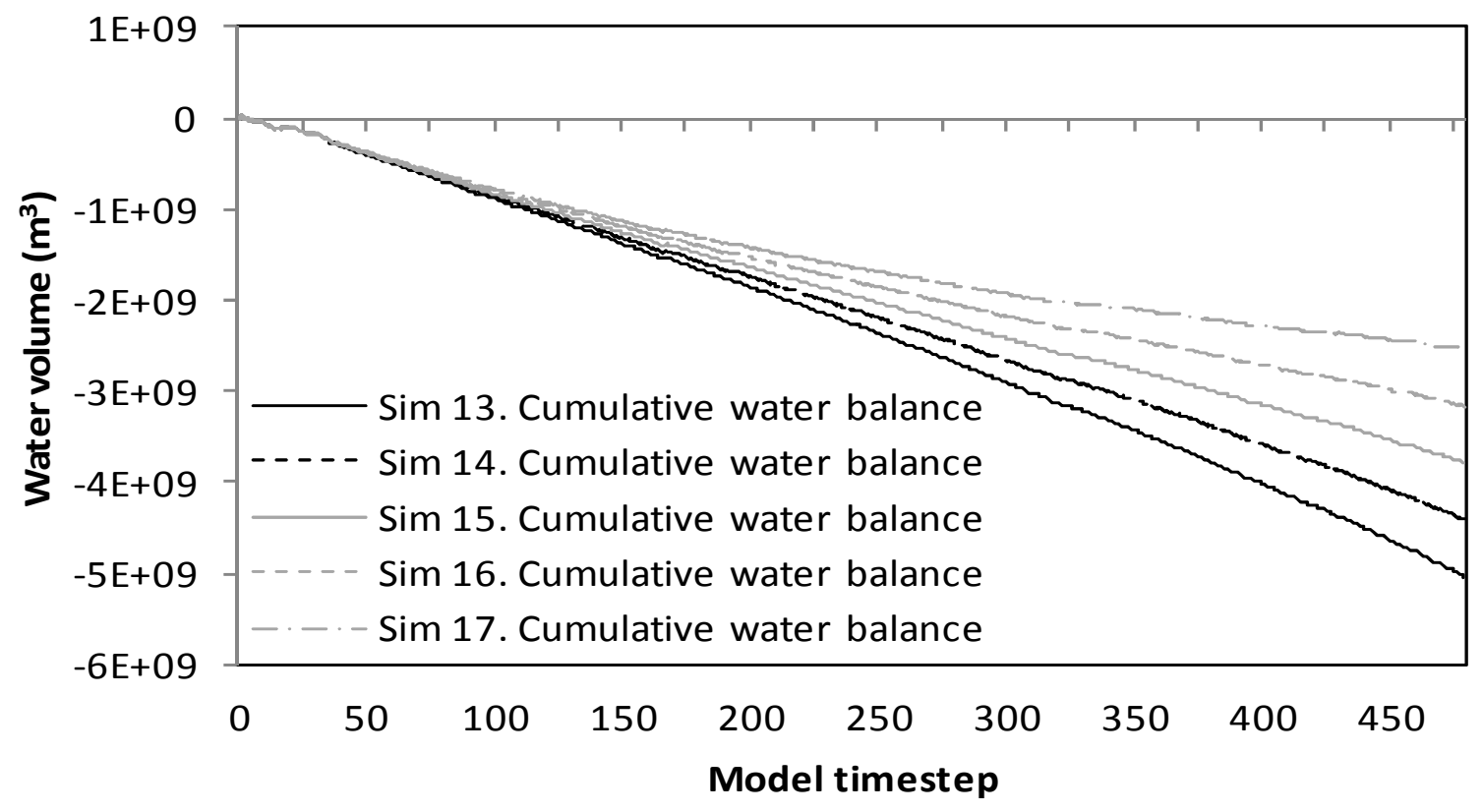


To be cited as: Sušnik, J., Vamvakeridou-Lyroudia, L.S., Gebert, N., Kloos, J., Renaud, F. La Jeunesse, I., Mabrouk, B., D.A. Savić, Kapelan, Z. Ludwig, R., Fischer, G., Roson, R., and Zografos, C., (2014), Interdisciplinary assessment of sealevel rise and climate change impacts on the lower Nile delta, Egypt, Science of the Total Environment, Vo. 503, pp. 279-288, doi: 10.1016/j.scitotenv.2014.06.111.

Figure 6

(a)

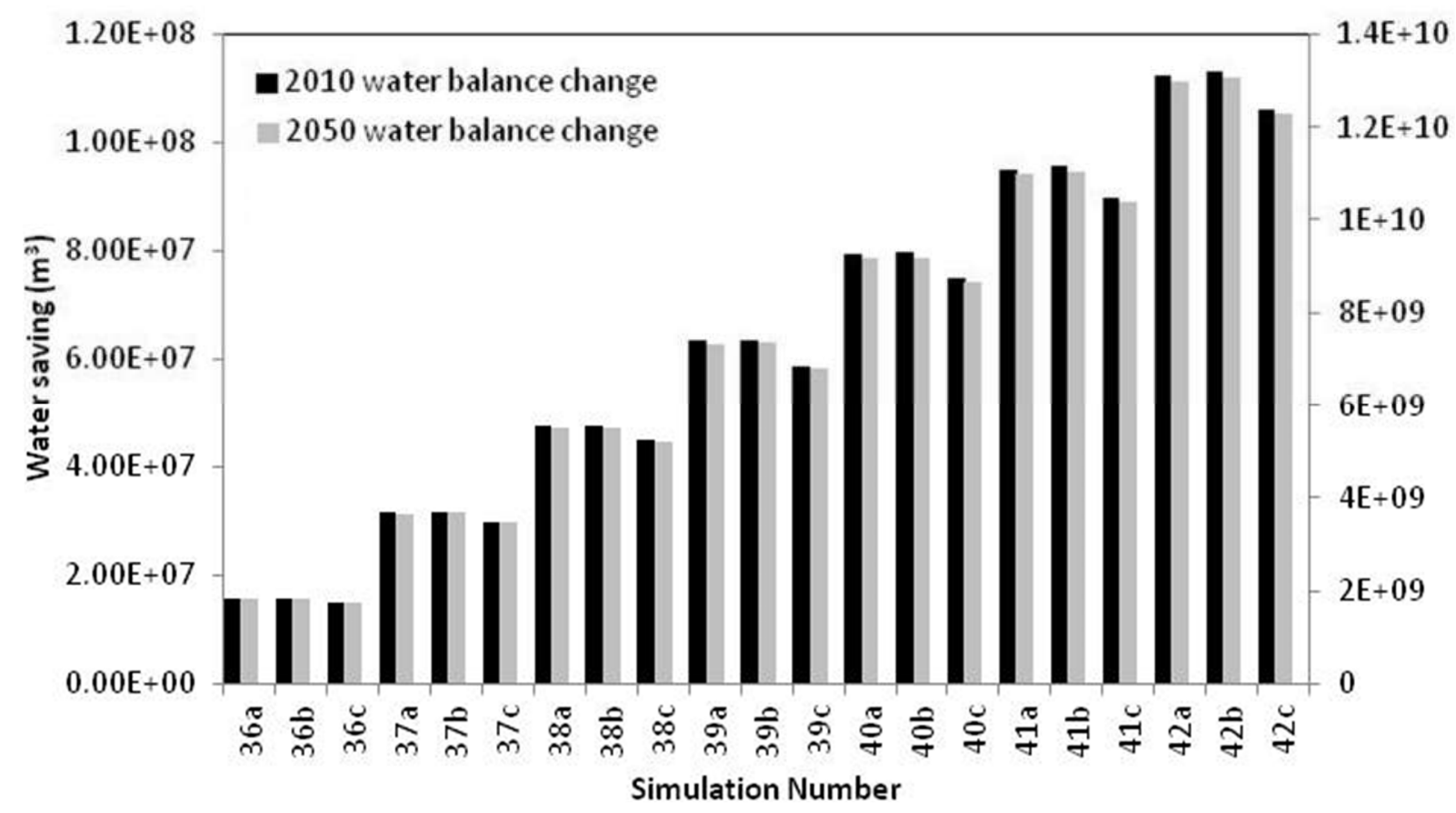

(b) 
To be cited as: Sušnik, J., Vamvakeridou-Lyroudia, L.S., Gebert, N., Kloos, J., Renaud, F. La Jeunesse, I., Mabrouk, B., D.A. Savić, Kapelan, Z. Ludwig, R., Fischer, G., Roson, R., and Zografos, C., (2014), Interdisciplinary assessment of sealevel rise and climate change impacts on the lower Nile delta, Egypt, Science of the Total Environment, Vo. 503, pp. 279-288, doi: 10.1016/j.scitotenv.2014.06.111.

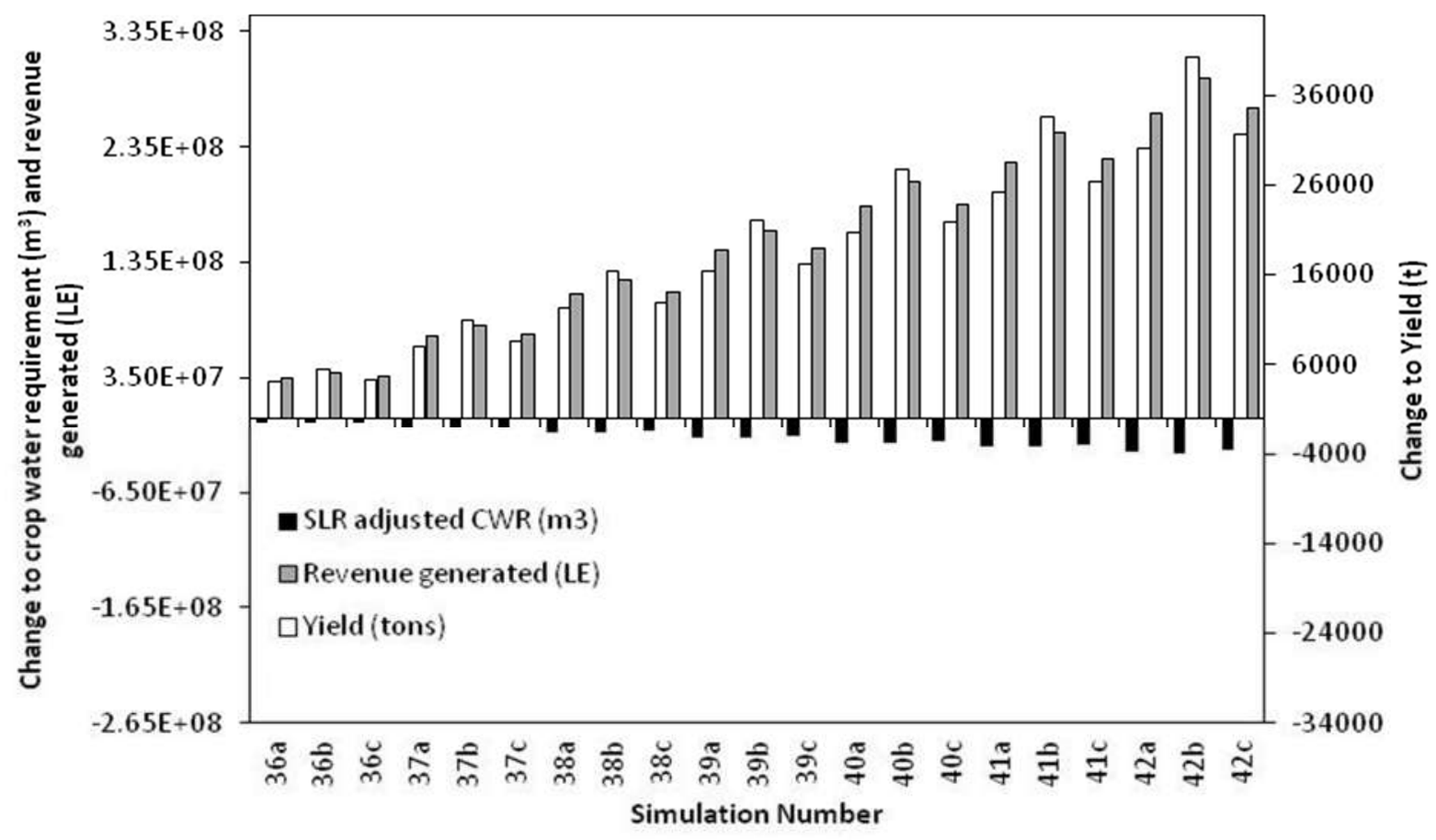

Figure 7

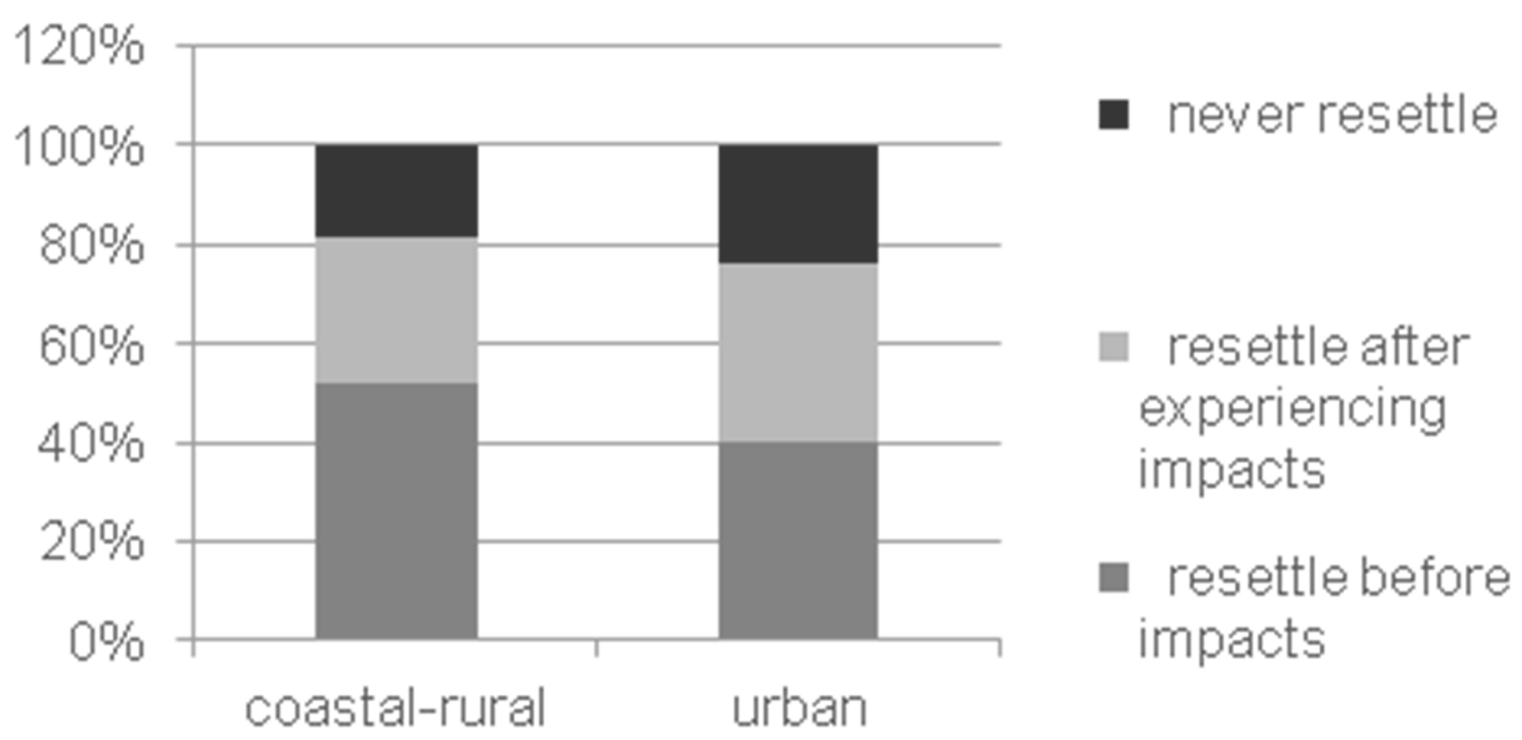

